\title{
単繊維引抜き試験によるカーボンナノチューブ/アルミナ複合材料の クラックブリッジング挙動特性評価*
}

\author{
山本剛 ${ }^{* 1}$, 白須圭一 ${ }^{* 2}$, 高木敏行 ${ }^{* 3}$, 橋田俊之 ${ }^{* 4}$
Evaluation of Crack Bridging Characteristics in Carbon Nanotube/Alumina Composites Using Single Fiber Pullout Testing Method

\author{
Go YAMAMOTO*1, Keiichi SHIRASU, Toshiyuki TAKAGI and Toshiyuki HASHIDA \\ ${ }^{* 1}$ Institute of Fluid Science, Tohoku University \\ 2-1-1, Katahira, Aoba-ku, Sendai, 980-8577 Japan
}

\begin{abstract}
The crack bridging behavior of multi-walled carbon nanotube-reinforced alumina matrix composites has been investigated using a single fiber pullout testing method. Contradictory to the conventional understanding (which have reported that pullout phenomena evidently occurred in the bulk nanotube-reinforced alumina composites), the pullout experiments using an in situ SEM method with a nanomanipulator system demonstrated that strong load transfer was revealed, and no pullout behavior was observed for all 15 MWCNTs. The MWCNTs, rather than pulling out from the alumina matrix, broke in the outer-shells and the inner section was pulled away, leaving the outer-shells of the fragment in the matrix. This implies that tougher ceramics with MWCNT can be obtained by creating the appropriate interaction between the matrix and MWCNT: not too week but also not too strong to permit an adequate load transfer between the two parts and thus a consequent pulling out without breakage of MWCNT. Our finding suggests important implications for the design of tougher ceramic composites with MWCNTs. The important factor for such tougher ceramic composites will thus be the use of 'strong' MWCNTs having higher mechanical performance (as well as a good dispersion in the matrix).
\end{abstract}

Key Words : Carbon Nanotubes, Ceramics, Composite Material, Crack Bridging Behavior, Single Fiber Pullout Tests

\section{1. 緒言}

カーボンナノチューブ（CNT）は，ナノ寸法の直径を有する円筒状の炭素繊維材料である ${ }^{(1)}$.グラフェンシー トを円筒状に丸めた継ぎ目のないシームレス構造に由来し, CNT は優れた力学, 電気伝導, 熱伝導特性を有して おり，多岐にわたる応用が期待されている(2). 特に注目すべき点は CNT の力学的特性にある. Espinosa $ら^{(3)}$ は, 透過型電子顕微鏡観察下で多層カーボンナノチューブ（MWCNT）単味の単軸引張実験を行い，その引張り強度 ならびに縦弾性係数はそれぞれ 97 110 GPa と 990 1100 GPa であったと報告している. これらの值は，従来の緎 維状材料に比べ 1 2 桁程度大きいことに加え, 炭素原子のみから構成される低密度材料であることから, MWCNT を樹脂，金属ならびにセラミックスの強化繊維として用いた複合材料の開発に関寸る研究が注目されている(4)(5). この種の繊維強化複合材料における䋊維と母材との界面構造と性質は, 複合材料の力学的ならびに物理的特性に 大きな影響を及ぼすことが知られている(6). 複合材料に荷重が負荷されたとき，その荷重は界面を介して母材か ら繊維へと伝達される。したがって, 繊維と母材との界面構造と性質の理解と制御は, MWCNT を強化要素とし て使用した複合材料の設計において重要である.

\footnotetext{
* 原稿受付 2010 年 10 月 29 日

*1 正員, 東北大学流体科学研究所（干980-8577 宮城県仙台市青葉区片平 2-1-1）

*2 学生員, 東北大学大学院環境科学研究科

*3 正員, フェロー, 東北大学流体科学研究所

*4 正員, フェロー, 東北大学工学研究科附属エネルギー安全科学国際研究センター

E-mail: gyamamoto@rift.mech.tohoku.ac.jp
} 

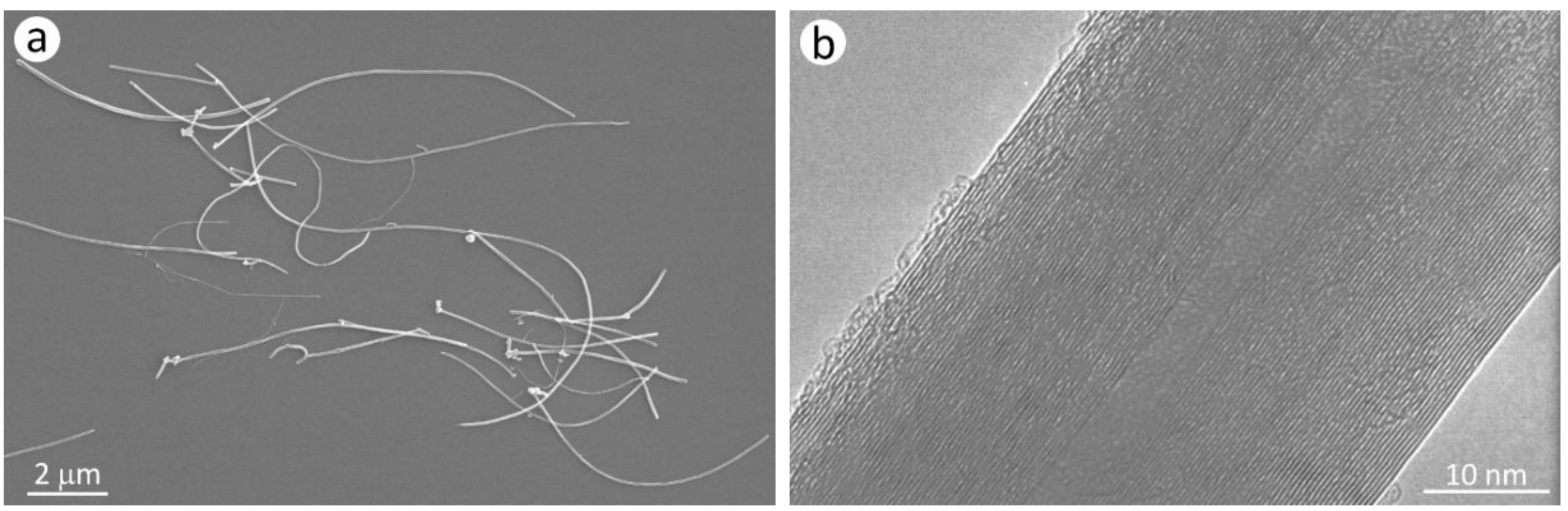

Fig. 1 (a) SEM and (b) TEM image of the MWCNTs used in this research.

本研究では，走査型電子顕微鏡（SEM）ならびに透過型電子顕微鏡（TEM）を用いた MWCNT/アルミナ複合 体の破面微細構造観察ならびに破面上に突出した1本のMWCNTのみを複合体から引抜く単繊維引抜き実験を実 施した。その結果，引張り荷重を負荷した MWCNT は引抜け挙動が誘起されるのではなく，MWCNT 固有の剣鞘型の破断挙動を示すことがわかった。この知見は，MWCNT の材料特性を活用した複合材料の設計において有 益な知見を提供するものと考えられるため, ここに報告をする.

\section{2. 実験方法}

本研究で使用した CNT は，多層カーボンナノチューブ（MWCNT）である．図 1 に MWCNT の SEM 像ならび に TEM 像を示す.SEM ならびに TEM を用いた観察結果から，本研究で使用した MWCNTの直径ならびに長さ は平均で $70 \mathrm{~nm}$ 程度 $(33 \sim 124 \mathrm{~nm})$ と $8.7 \mu \mathrm{m}$ 程度 $(1.1 \sim 22.5 \mu \mathrm{m})$ であった. MWCNT は，長く平坦な炭素六角網 面層が繊維軸に対して平行に配列しており，良好な結晶性を有していることがわかる（図 1b）。アルミナの合成 には水酸化アルミニウムを複合体作製の出発原料に使用した前駆体法を用いて行った ${ }^{(7)(8)}$. 複合体の作製は，放電 プラスマ焼結法を用いて行った ${ }^{(7)(8)}$ 。複合体の破面構造観察は，走査型電子顕微鏡（SEM, Hitachi S-4300）ならび に透過型電子顕微鏡（TEM, Hitachi HF-2000）を用いて行った．SEM を使用した破面観察は，三点曲げ試験後の破 断面を有する試験片を供試体として用いた. TEM を使用した破面観察は, 試料の厚みが $50 \mu \mathrm{m}$ 程度になるまで機械加 工を施した後，ピンセットを用いて曲げ荷重を負荷し破断させることで破断面を作製した.これを銅製のグリッドに接着固 定することで観察の供試体とした. 単䋊維引抜き試験は，XY 軸ステージと Z 軸ステージを備えたマニピュレータ(9) を用いて SEM 観察下において行った。単繊維引抜き実験に供した複合体は，MWCNTを 0.9 vol.\%含んでおり， その相対密度は $98.9 \%$ であ，曲げ強度ならびに破壊勒性值は， $543.8 \pm 60.9 \mathrm{MPa}$ ならびに $4.73 \pm 0.12 \mathrm{MPa} \cdot \mathrm{m}^{1 / 2}$ で あった ${ }^{(10)}$. Si 製の片持ち梁（PPP-ZEILR, nominal force constant $1.6 \mathrm{~N} / \mathrm{m}$; NANOSENSORS）と SEM 観察時のチャー ジアップ現象を抑制する目的で Pt 製の導電性コーティング処理を施した破断面を有する複合体をそれぞれ XY
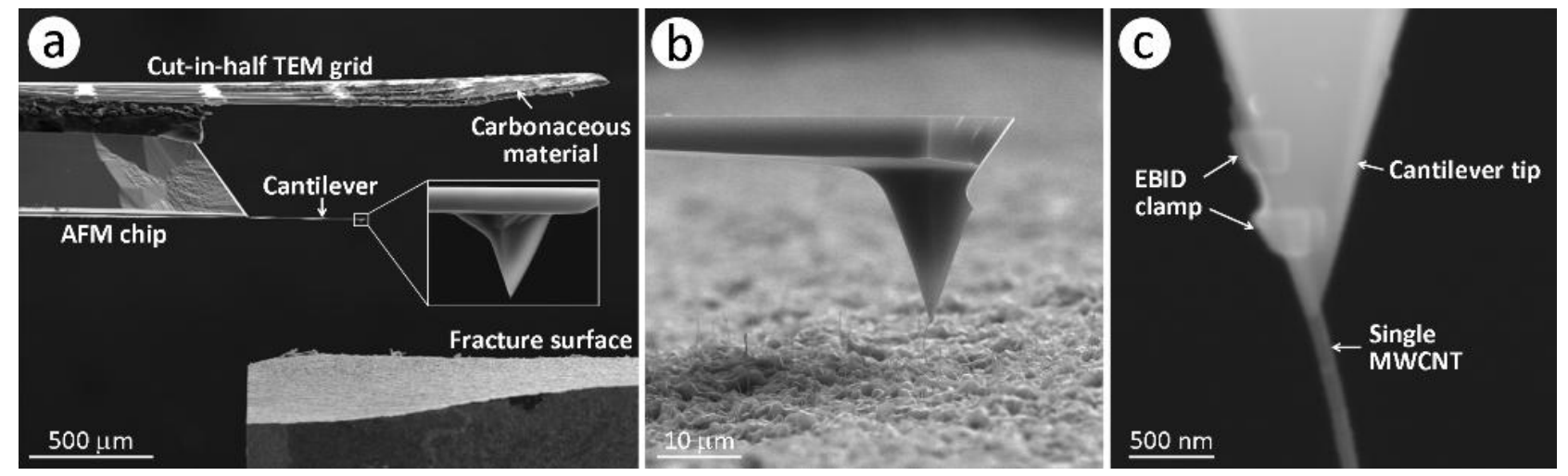

Fig. 2 SEM images showing the experimental setup for the single fiber pullout tests. 
軸ステージならびに Z 軸ステージに固定した（図 2a）。破面に突出した MWCNT と片持ち梁とを電子線蒸着法 ${ }^{(1)}$

(EBID 法) を用いて固定した (図 2c)，約 $100 \mathrm{~nm} / \mathrm{s}$ の変位速度で片持ち梁に変位を与えることで MWCNTに引 張り荷重を負荷し，片持ち梁のたわ及角度の変化から荷重を算出した ${ }^{(11)}$.

\section{3. 実験結果}

図 3 に複合体破面の SEM 像ならびに TEM 像を示寸.SEM 観察では（図 3a），アルミナ母材から引抜けを生じ たと思われる多数の MWCNT が観察された. MWCNT の突出長さは $0 \sim 11.8 \mu \mathrm{m}$ であり，平均值は $2.8 \mu \mathrm{m}$ であっ た．母材に使用したアルミナは粒界破壊が支配的であり，MWCNT はアルミナの粒界から突出している様子が認 められた。同試料における TEM 観察からは, 図3bに例示されるように, SEM の分解能では判別が困難であった 直径変化を有する MWCNT が多数観察された。 これは, MWCNT に単軸引張り荷重を負荷した際に認められる MWCNT 固有の剣-鞘型の破断形態 ${ }^{(3)(9)(11)}$ に類似している.これらの観察結果は, 複合体の破断時に一部の MWCNT は完全に引抜けるのではなく，最外層を含む数層が破断を生じることを示唆するものである.

次に MWCNT 単味の引抜き実験結果について記述する。単繊維引抜き実験は，SEM 観察にて損傷の含まれて いないと思われる 15 本の MWCNT を選択し実施した。図 4 に代表的な引抜き実験前後の SEM 像およびTEM 像 を示す.アルミナの粒界から突出した $5.7 \mu \mathrm{m}$ 程度の長さを有する MWCNT（図 4a）と片持ち梁とを EBID 法を用 いて固定した後，片持ち梁に変位を与えることでMWCNTに引張り荷重を負荷した．実験後の複合体の破面（図 4b）からは，引抜き実験に供した MWCNT の断片がアルミナの粒界に存在している様子が観察される. 一方，片 持ち梁に固定された MWCNT の長さは $10.9 \mu \mathrm{m}$ 程度であり（図 4c), 複合体破面からの突出長さ（約 $5.7 \mu \mathrm{m}$ ) と 比べ明らかに長くなっていることがわかる. また, 図 $4 \mathrm{~d}$ と図 $4 \mathrm{e}$ に示されるように, 複合体破面近傍に位置して いた個所からは MWCNT の直径変化が認められることに加え, 複合体内部から引抜かれた MWCNT の先端部は 閉口している様子が観察される. 複合体破面から突出した MWCNT の直径が約 $94 \mathrm{~nm}$ であったのに対し, 複合体 内部から引抜かれた MWCNT の直径は約 $90 \mathrm{~nm}$ であることから, MWCNT の層間距離(12)を $0.34 \mathrm{~nm}$ と仮定すると， 約 11 層のチューブが破断を生じたことが考えられる.これらの観察結果は，SEM 観察に基づく従来の破壊プロ セスの理解 ${ }^{(13)(14)}$ とは異なり, MWCNT はアルミナ母材から完全に引抜けるのではなく最外層を含む数層が破断を 生じた後, 内側の層が最外層を含む層から引抜けたことを示唆している. 本研究で引抜き実験に供した 15 本の MWCNT は，いずれも完全に引抜けるのでなく最外層を含む数層が破断を生じる MWCNT に固有の剣-鞘型の破 壞挙動を示寸ことがわかった. TEM を用いた破面構造観察で認められた MWCNT 固有の破壞挙動が単繊維引抜 き実験下においても生じることが明らかとなり,この MWCNT 固有の破壊挙動がアルミナの強化繊維として使用 した MWCNT の主たる破壊の様式であることが考えられる.

単繊維引抜き実験から得られた MWCNT の破断荷重は平均で $14.4 \mu \mathrm{N}$ であった. この值は, 複合体作製に使用 した MWCNT と同じ種類の MWCNT の単軸引張り試験から得られた平均破断荷重 ${ }^{(11)}(6.4 \mu \mathrm{N})$ の約 2.3 倍である. この荷重保持能力の増大は, 現時点では明確ではない，しかしながら，これまでの TEM 観察によると破面上に 突出した MWCNT は, 出発原料では認められない炭素六角網面層の配向が䋊維軸に対して完全に平行ではない不 定形構造を有していることが観察されている. 上述した破断荷重の増大は，この構造変化に起因する MWCNT の 層間における荷重伝達能力の向上が主たる理由であることが考えられる.
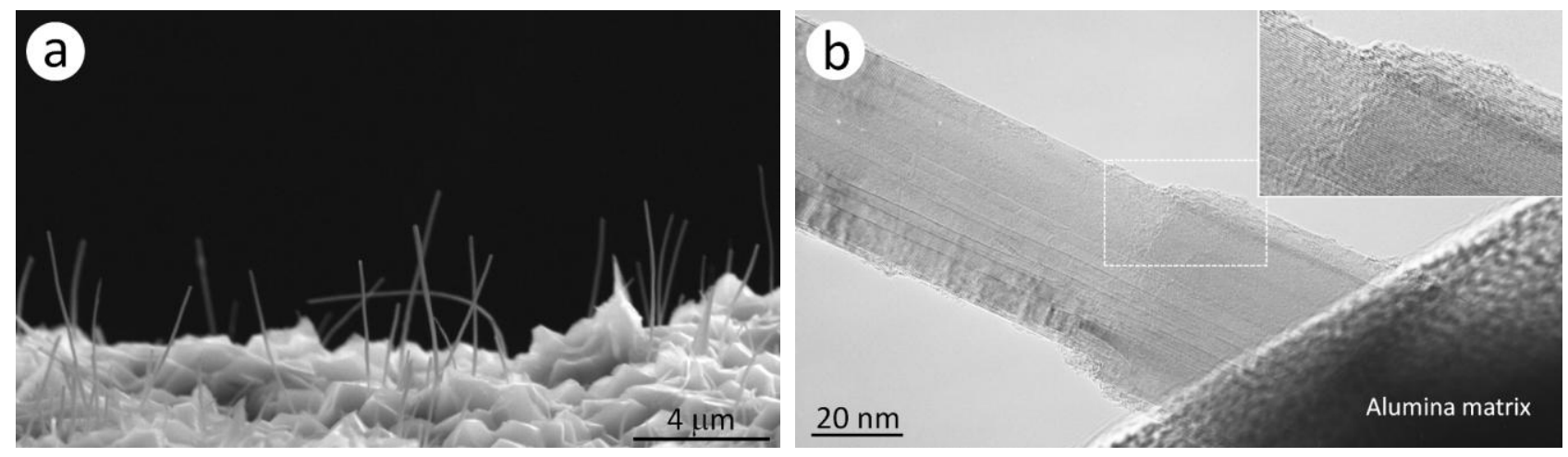

Fig. 3 Fracture surface of the MWCNT/alumina composite acquired by (a) SEM and (b) TEM. 


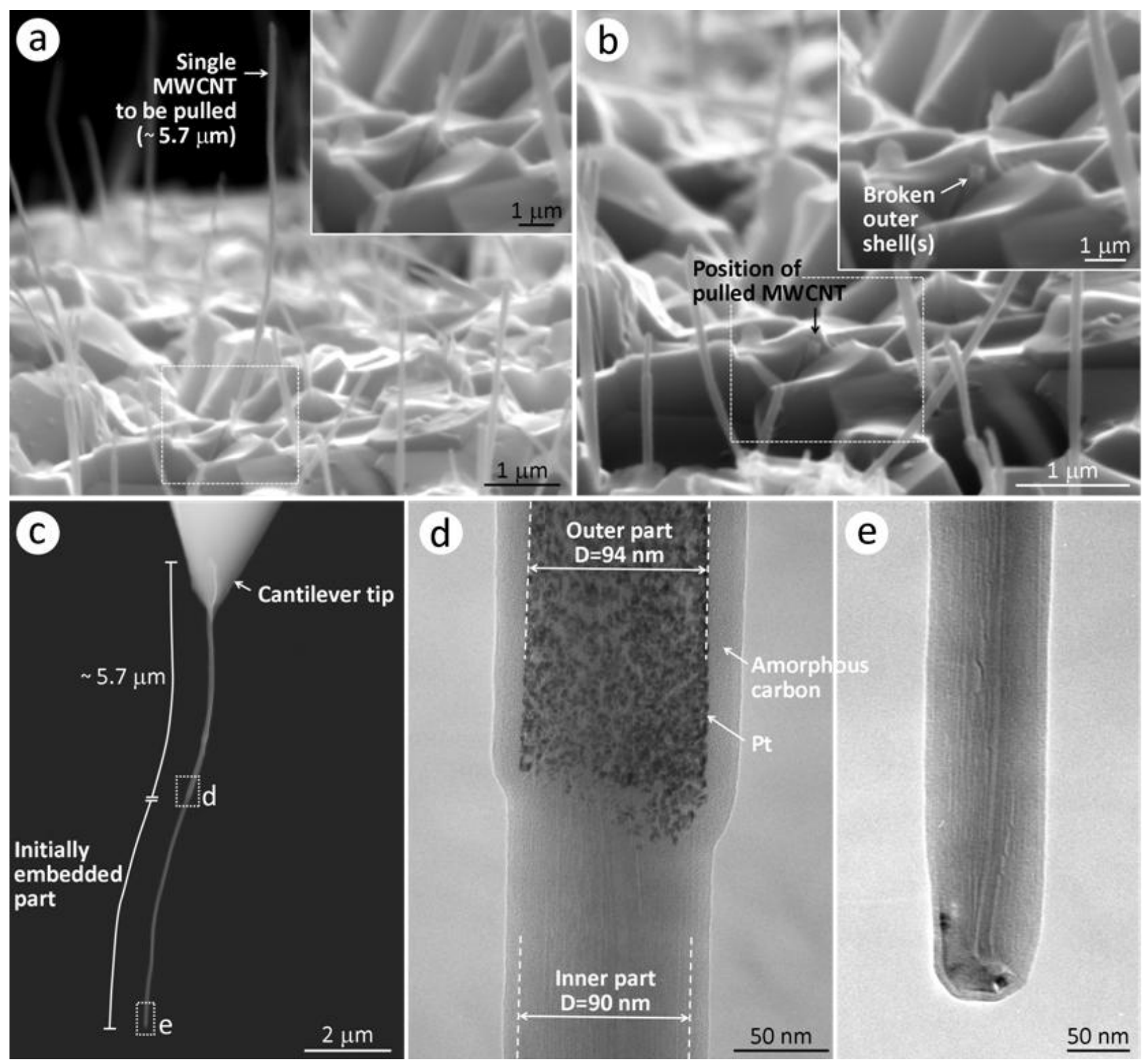

Fig. 4 A series of SEM and TEM images for the single MWCNT captured (a) before and (b,c,d,e) after its breaking.

強化䋊維を配合することによる母材の高勒化機構は，今日においてよく確立されている( ${ }^{(6)}$.この種の複合材料

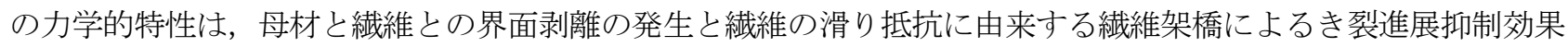
に支配され，この界面破壊挙動が，䋊維強化複合材料の高勒化に大きく寄与寸ることが知られている，一方，本 研究においては, 複合体破面の TEM 観察ならびに単繊維引抜き実験結果に示されるように, MWCNT 固有の破 壊挙動が MWCNT の主たる破壊様式であると推察され，MWCNT を配合することによるき裂進展抑制効果が制 限されている可能性が考えられる，上述のように，界面剥離の発生と繊維の滑り抵抗に起因寸るき裂進展抑制効 果は複合体の高勒化に大きく寄与する(6) ことから，複合材料のさらなる破壊特性の向上のためには，MWCNT の 破断を防止することが有効であることを示しており，本研究で得られた結果は，MWCNT の材料特性を活用した 複合材料の設計において重要な知見を提供するものである. 本研究で強化繊維に使用した MWCNT の破断強度は 平均で $20 \mathrm{GPa}$ であり ${ }^{(11)}$, 既往の報告例にある MWCNT の破断強度 ${ }^{(3)}(97 \sim 110 \mathrm{GPa})$ に比べその值は小さい. MWCNT の有する軽量かつ極めて高強度な特性を十分に生かした複合体の作製には, より荷重保持能力に優れた MWCNT を使用することで，母材と繊維間におけるき裂架橋応力の向上を図る必要がある. 


\section{4. 結 語}

本研究では, セラミックスの強化要素として使用した MWCNT とセラミックス母材との界面構造と性質を理解 する目的で, SEM ならびに TEM を用いた MWCNT/アルミナ複合体の破面微細構造観察を実施した. また, より 直接的な CNT のクラックブリッジング挙動を理解する目的で, 破面上に突出した 1 本の MWCNT のみを複合体 から引抜く単繊維引抜き実験を実施した. SEM 観察に基づく従来の破壊プロセスの理解とは異なり, 単繊維引抜 き実験に供した 15 本の MWCNT は，いずれもアルミナ母材から完全に引抜けるのではなく最外層を含む数層が 破断を生じた後, 内側の層が最外層を含む層から引抜ける MWCNT に固有の剣-鞘型の破壊挙動を示すことがわ かった.この MWCNT 固有の破壊挙動がアルミナ基複合体に含まれる MWCNT の主たる破壊様式であると推察 され，MWCNT を配合することによるき裂進展抑制効果が制限されている可能性が考えられる．複合材料のさら なる破壊特性の向上のためには，MWCNT の破断を防止することが有効であることを示すものである.

\section{謝 辞}

本研究を遂行するに当たり，貴重なご支援を頂きました相沢養市氏，鈴木南枝氏ならびに宮崎孝道氏に謝意を 表します. 本研究は基盤研究（S）（21226004）ならびに特別研究員奨励費（08J09683）の助成を受けたものであ る. 本研究の一部は, 東北大学金属材料研究所付属金属ガラス総合研究センターの共同利用研究によったことを 記し謝意を表します.

\section{文献}

(1) Iijima, S., and Ichihashi, T., "Single-shell Carbon Nanotubes of 1-nm Diameter", Nature, Vol. 363, (1993), pp. 603-605.

(2) Baughman, R.H., Zakhidov, A.A., and de Heer, W.A., "Carbon Nanotube - the Route Toward Applications", Science, Vol. 297, (2002), pp. 787-792.

(3) Peng, B., Locascio, M., Zapol, P., Li, S., Mielke, S.L., Schatz, G.C., and Espinosa, H.D., "Measurements of Near-ultimate Strength for Multiwalled Carbon Nanotubes and Irradiation-induced Crosslinking Improvements", Nature Nanotechnology, Vol. 3, (2008), pp. 626 - 631.

(4) Harris, P.J.F., "Carbon Nanotube Composites" (Review), International Materials Reviews, Vol. 49, (2004), pp. 31-43.

(5) Cho, J., Boccaccini, A.R., and Shaffer, M.S.P., "Ceramic Matrix Composites Containing Carbon Nanotubes" (Review), Journal of Materials Science, Vol. 44, (2009), pp. 1934-1951.

(6) Hull, D., and Clyne, T.W., "An Introduction to Composite Materials", (1996), Cambridge University Press.

(7) Yamamoto, G. Omori, M., Yokomizo, K., Hashida, T., and Adachi, K., "Structural Characterization and Frictional Properties of Carbon Nanotube/Alumina Composites Prepared by Precursor Method", Materials Science and Engineering B-Advanced Functional Solid-State Materials, Vol. 148, (2008), pp. 265-269.

(8) Yamamoto, G., Omori, M., Hashida, T., Kimura, H., and Takagi T., "Effects of Sintering Additive on Mechanical Properties of Alumina Matrix Composites Reinforced with Carbon Nanotubes", Journal of Solid Mechanics and Materials Engineering, Vol. 4, (2010), pp. 460-469.

(9) Yu, M.F., Lourie, O., Dyer, M.J., Moloni, K., Kelly, T.F., and Ruoff, R.S., "Strength and Breaking Mechanism of Multiwalled Carbon Nanotubes Under Tensile Load”, Science, Vol. 287, (2000), pp. 637-640.

(10) Yamamoto, G., Omori, M., Hashida, T., and Kimura, H., "A Novel Structure for Carbon Nanotube Reinforced Alumina Composites with Improved Mechanical Properties”, Nanotechnology, Vol. 19, (2008), article number 315708.

(11) Yamamoto, G., Suk, J.W., An, J., Piner, R.D., Hashida, T., Takagi, T., and Ruoff, R.S., "The Influence of Nanoscale Defects on the Fracture of Multi-walled Carbon Nanotubes Under Tensile Loading", Diamond \& Related Materials, Vol. 19, (2010), pp. 748-751.

(12) Iijima, S., "Helical Microtubules of Graphitic Carbon", Nature, Vol. 354, (1991), pp. 56-58.

(13) Flahaut, E., Peigney, A., Laurent, Ch., Marlière, Ch., Chastel, F., and Rousset, A., "Carbon Nanotube-Metal-Oxide Nanocomposites: Microstructure, Electrical Conductivity and Mechanical Properties", Acta Materialia, Vol. 48, (2000), pp. 3803-3812.

(14) Xia, Z., Riester, L., Curtin, W.A., Li, H., Sheldon, B.W., Liang, J., Chang, B., and Xu, J.M., "Direct Observation of Toughening Mechanisms in Carbon Nanotube Ceramic Matrix Composites”, Acta Materialia, Vol. 52, (2004), pp. 931-944. 